\title{
Phytochemical Analysis, Cytotoxic and In vitro Antioxidant Activity of Erythrina variegate Bark
}

\author{
Mohammad Shahriar ${ }^{{ }^{\star}}$, Nishat Zareen Khair ${ }^{2}$, Zara Sheikh ${ }^{2}$, \\ Sayeeda Fahmee Chowdhury ${ }^{1}$, Md. Kamruzzaman ${ }^{1}$, \\ Md. Shawkatul Islam Bakhtiar ${ }^{1}$, Sharmin Jahan Chisty ${ }^{1}$, \\ Syeda Najah Narjish ${ }^{1}$, Rumana Akhter ${ }^{1}$ and Nahia Akter ${ }^{1}$ \\ ${ }^{1}$ Phytochemistry Research Laboratory, University of Asia Pacific, Dhaka, Bangladesh. \\ ${ }^{2}$ Department of Pharmacy, BRAC University, Dhaka, Bangladesh.
}

Authors' contributions

This work was carried out in collaboration between all authors. Authors MS, NZK and NA designed the study. Authors MK, MSIB and SJC managed the analyses of the study. Authors SNN and RA performed statistical analysis. Authors MS and RA wrote the protocol. Authors MS, NZK and NA wrote the first draft of the manuscript. Authors ZS, SNN and SFC contributed the literature searches. All authors read and approved the final manuscript.

Article Information

DOI: $10.9734 / E J M P / 2016 / 18866$

Editor(s):

(1) Marcello Iriti, Professor of Plant Biology and Pathology, Department of Agricultural and Environmental Sciences,

Milan State University, Italy.

Reviewers:

(1) M. Angels calvo torras, Universitat Autonoma De Barcelona, Spain. (2) Atef Mahmoud Mahmoud Attia, National Research Centre, Egypt. (3) Anonymous, Mexico. (4) B. Dewprashad, City University of New York, USA. Complete Peer review History: http://sciencedomain.org/review-history/12216

Short Research Article

Received $13^{\text {th }}$ May 2015 Accepted $16^{\text {th }}$ October 2015 Published $9^{\text {th }}$ November 2015

\section{ABSTRACT}

Aim: The objective of the present study was to investigate the phytochemical analysis, cytotoxic and antioxidant activities of the bark extracts of Erythrina variegate.

Place and Duration of Study: The plant, E. variegate was collected from Botanical Garden, Mirpur, Dhaka and also from Curzon Hall, University of Dhaka, Bangladesh in June 2014 and then the sample was identified by the National Herbarium of Bangladesh, Mirpur, Dhaka (DACB; Accession Number- 36148).

Methodology: Preliminary phytochemical screening was done for determining the nature of phytoconstituents. Brine shrimp lethality bioassay technique was done to study the cytotoxic 
properties. Aluminum chloride colorimetric method was applied for the determination of flavonoids and the total antioxidant ability was assessed by the phospho-molybdenum method.

Results: Primary phytochemical analysis confirmed the presence of alkaloid, carbohydrate, glycosides and flavonoids. The extracts showed some toxicity to $A$. salina with $\mathrm{LC}_{50}$ values ranging from 1.41 to $3.66 \mu \mathrm{g} / \mathrm{ml}$ which was compared with standard vincristine sulphate (VS, LC 50 value $0.92 \mu \mathrm{g} / \mathrm{ml}) . \mathrm{n}$-Hexane extract of $E$. variegate was found to contain highest amount of flavonoids $(3.77 \pm 1.97 \mathrm{mg} / \mathrm{gm}$; quercetin equivalent) and ethanol extract of $E$. variegate was found to have highest antioxidant acitivity $(2.03 \pm 0.09 \mathrm{mg} / \mathrm{gm}$ ascorbic acid equivalent).

Conclusion: It can be concluded that the plant extracts of $E$. variegate possess several antioxidant activities which justifies its use as folk medicine.

Keywords: Erythrina variegate; phytochemicals; antioxidant capacities; cytotoxicity.

\section{INTRODUCTION}

Traditionally medicinal plants are widely used for the treatment of many diseases. The plants may contain chemical compounds which have the property of drugs or can act as precursor for the synthesis of useful drugs [1]. The ancient literatures include many plants for their medicinal values and they have been found to be effective for the treatment of various diseases which play significant role in providing primary healthcare services to rural and poor people who cannot afford costly and rare synthetic drugs. Moreover, these plants can act as a major source of income by exporting medicinal plants to other countries [2].

Erythrina variegate belongs to Fabaceae family. The genus, Erythrina includes about 110 species which are collectively known as "coral tree". The coral tree is cultivated particularly as an decorative tree and as a shade and also as a soil improvement tree (it fixes nitrogen) for other trees and crops such as coffee and cacao [3]. The plant parts from $E$. variegate are widely used for the treatment of different disease complications. The leaves are employed for their antispasmodic, anthelmintic, laxative, diuretic, galactagogue and emmenagogue properties. They are also applied externally for dispersing venereal buboes, relieving pain and inflammation of the joints [4]. Its juice is used to the ear to relieve ear ache and is used as an anodyne in toothache. The bark is used for its astringent, febrifuge anti-bilious and anthelmintic properties; It is also useful in dysentery and as a collyriumin ophthalmia. The roots are emmenagogue [5].

The objective of the present study was to investigate the phytochemical properties, in vitro cytotoxic activity and in vitro antioxidant activities of the bark extracts of $E$. variegate.

\section{MATERIALS AND METHODS}

\subsection{Collection, Identification and Processing of Plant Sample}

The bark extracts of Erythrina variegate was collected from the Botanical garden, Dhaka and Curzon Hall, University of Dhaka in June 2014 and was taxnomically identified with the help of the National Herbarium of Bangladesh, Mirpur-1, Dhaka (DACB; Accession Number- 36148). Bark was sun dried for seven days. The dried bark were then ground in to coarse powder using high capacity mixer grinding machine (Jaipan designer mixer grinder, jaipan, India), which was then stored in air-tight container with necessary markings for identification and kept in cool, dark and dry place for the investigation.

\subsection{Extraction Procedure}

The powdered plant parts $(500 \mathrm{gm})$ were successively extracted in a soxhlet extractor at elevated temperature using $250 \mathrm{ml}$ of distilled methanol $(40-60)^{\circ} \mathrm{C}$ which was followed by ethanol, chloroform, petroleum and $n$-hexane. After extraction all extracts were labeled and kept in refrigerator at $4^{\circ} \mathrm{C}$ for future investigation.

\subsection{Preliminary Phytochemical Screening}

One gram of the methanol extract of Erythrina variegate was dissolved in $100 \mathrm{ml}$ of methanol and was subjected to preliminary phytochemical screenings for determining nature of phytoconstituents $[5,6]$.

\subsection{Brine Shrimp Lethality Bioassay}

Brine shrimp lethality bioassay $[7,8]$ technique was applied for the determination of general toxic properties of the plant extracts. Dimethylsulfoxide (DMSO) solutions of the samples were applied against Artemia salina in a 1-day in vivo assay. 
For the experiment, $1 \mathrm{mg}$ of each extracts were added with $5 \mathrm{ml}$ of sea water. Concentration was found to be $200 \mu \mathrm{g} / \mathrm{ml}$. Then $50 \mu \mathrm{l}$ DMSO was added to these and sample was prepared. Then the solution was serial diluted to $100,50,25$, $12.5,6.25,3.125,1.563 \mu \mathrm{g} / \mathrm{ml}$ with sea water. Then $2.5 \mathrm{ml}$ of plant extract solution was added to $2.5 \mathrm{ml}$ seawater containing 10 nauplii. Vincristine Sulphate (VS) was used as positive control.

\subsection{Determination of Total Flavonoids Content}

Aluminum chloride colorimetric method was used for flavonoids determination [9]. $1 \mathrm{ml}$ of the plant extracts/standard of different concentration solution was mixed with $3 \mathrm{ml}$ of methanol, $0.2 \mathrm{ml}$ of aluminum chloride, $0.2 \mathrm{ml}$ of $1 \mathrm{M}$ potassium acetate and $5.6 \mathrm{ml}$ of distilled water. It was then kept at room temperature for $30 \mathrm{~min}$ and the absorbance of the reaction mixture was measured at $415 \mathrm{~nm}$ wavelength with UV-VIS spectrophotometer (UV-1280, UV-VIS spectrophotometer, Shimadzu, Japan) against blank. Methanol was used as blank. The total content of flavonoid compounds in methanol extracts of the plant in quercetin equivalents was calculated by the following equation:

$$
C=(c \times V) / m
$$

where; $\mathrm{C}=$ total content of flavonoid compounds, $\mathrm{mg} / \mathrm{gm}$ plant extract, in quercetin equivalent, $c=$ the concentration of quercetin established from the calibration curve in $\mathrm{mg} / \mathrm{ml}, \mathrm{V}=$ the volume of extract in $\mathrm{ml}$ and $\mathrm{m}=$ the weight of crude plant extract in gm.

\subsection{Determination of Total Antioxidant Capacity}

The total antioxidant capacity was evaluated by the phosphomolybdenum method [10,11]. $0.3 \mathrm{ml}$ of extract and sub-fraction in ethanol, ascorbic acid used as standard $(5-200 \mu \mathrm{g} / \mathrm{ml})$ and blank (ethanol) were combined with $3 \mathrm{ml}$ of reagent mixture separately and incubated at $95^{\circ} \mathrm{C}$ for 90 minutes. After cooling to room temperature, the absorbance of each sample was measured at $695 \mathrm{~nm}$ against the blank. The antioxidant activity is expressed as the number of equivalents of ascorbic acid and was calculated by the following equation:

$$
A=(c \times V) / m
$$

where, $\mathrm{A}=$ total content of Antioxidant compounds, $\mathrm{mg} / \mathrm{gm}$ plant extract, in Ascorbic acid Equivalent, $\mathrm{c}=$ the concentration of ascorbic acid established from the calibration curve, $\mathrm{mg} / \mathrm{ml}, \mathrm{V}=$ the volume of extract in $\mathrm{ml}, \mathrm{m}=$ the weight of crude plant extract, gm.

\section{RESULTS AND DISCUSSION}

\subsection{Preliminary Phytochemical Screening}

In primary phytochemical screening, methanol, ethanol, pet-ether and chloroform extracts of E. variegate was found to contain alkaloid, carbohydrate, glycosides and flavonoids although the saponin was absent in chloroform, pet-ether and n-hexane extracts. Phenols, steroids and tannins were absent in all the extracts (Table 1).

\subsection{Brine Shrimp Lethality Bioassay}

In the brine shrimp lethality bioassay the $\mathrm{LC}_{50}$ value of the test samples after 24 hours was obtained by a plot of percentage of the shrimps died against the logarithm of the sample concentration. The best-fit line was obtained from the curve data by means of regression analysis.

Vincristine Sulphate (VS) was used as positive control, $\mathrm{LC}_{50}$ was found to be $0.92 \mu \mathrm{g} / \mathrm{ml}$.

Table 1. Analysis of phytochemicals in the different extracts of Erythrina variegate

\begin{tabular}{llllll}
\hline Name of tests & \multicolumn{5}{c}{ Name of extracts } \\
\cline { 2 - 6 } & Methanol & Ethanol & Chloroform & Pet-ether & n-Hexane \\
\hline Alkaloids & + & + & + & + & + \\
Carbohydrates & + & + & + & + & + \\
Flavonoids & + & + & + & + & + \\
Glycosides & + & - & - & + & + \\
Phenols & - & - & - & - & - \\
Saponins & + & - & - & - & - \\
Steroids & - & - & - & - & - \\
Tannins & - & - & & & - \\
\hline
\end{tabular}

(+) Presence \& (-) Absent 
The $\mathrm{LC}_{50}$ values of methanol, ethanol, chloroform, n-hexane and pet-ether extracts of E. variegate are presented in Table 2 .

Table 2. $\mathbf{L C}_{50}$ values of the five extracts of Erythrina variegate and standard

\begin{tabular}{ll}
\hline Test samples & LC $_{\mathbf{5 0}}$ \\
\hline Vincristine sulphate (standard) & 0.92 \\
Methanol & 3.66 \\
Ethanol & 3.12 \\
Chloroform & 1.45 \\
n-Hexane & 1.41 \\
Petrolium ether & 1.92 \\
\hline
\end{tabular}

\subsection{Total Flavonoid Content}

Aluminium chloride colorimetric method was used to determine total flavonoid content of different extracts of $E$. variegate. Total flavonoids content was determined using the standard curve of quercetin ( $\left.y=0.690 x-0.689 ; R^{2}=0.761\right)$ and was expressed as Quercetin Equivalents (QE) per gram of the plant extract. $\mathrm{N}$-Hexane extract of $E$. variegate was found to contain the highest amount of flavonoids (Table 3 ).

Table 3. Total flavonoid contents of the different extracts of Erythrina variegate

\begin{tabular}{ll}
\hline Name of extracts & $\begin{array}{l}\text { Total flavonoid content } \\
\text { (mg/gm; quercetin } \\
\text { equivalent) }\end{array}$ \\
\hline Methanol & $2.09 \pm 0.07$ \\
Ethanol & $2.26 \pm 0.11$ \\
Chloroform & $2.33 \pm 0.32$ \\
Petroleum ether & $3.55 \pm 1.63$ \\
$\mathrm{n}$-Hexane & $3.77 \pm 1.97$ \\
\hline \multicolumn{2}{c}{ Values are the mean of duplicate experiments and } \\
\multicolumn{2}{c}{ represented as mean $\pm S D$}
\end{tabular}

\subsection{Total Antioxidant Capacity}

Total antioxidant capacity of the different extracts of $E$. variegate was evaluated by the phosphomolybdenum method and was expressed as ascorbic acid equivalents per gram of plant extract. Total antioxidant capacity of the test samples was calculated using the standard curve of ascorbic acid ( $\left.y=1.076 x-0.808 ; R^{2}=0.953\right)$. The ethanol extract of was found to possess highest amount of antioxidant (Table 4).
Table 4. Total antioxidant capacity of the different extracts of Erythrina variegate

\begin{tabular}{ll}
\hline $\begin{array}{l}\text { Name of } \\
\text { extracts }\end{array}$ & $\begin{array}{l}\text { Total anti-oxidant } \\
\text { capacity }(\mathbf{m g} / \mathbf{g m}), \\
\text { ascorbic acid equivalent }\end{array}$ \\
\hline Methanol & $1.89 \pm 0.49$ \\
Ethanol & $2.03 \pm 0.09$ \\
Chloroform & $1.77 \pm 0.26$ \\
Petroleum ether & $1.41 \pm 0.27$ \\
$\mathrm{n}$ - Hexane & $1.55 \pm 0.25$ \\
\hline \multicolumn{2}{c}{ Values are the mean of duplicate experiments and } \\
\multicolumn{2}{c}{ represented as mean $\pm S D$}
\end{tabular}

\section{CONCLUSION}

After the screening of the phytoconstituients showed the presence of glycosides, carbohydrates, alkaloids, saponins, flavonoids and steroids. The $\mathrm{n}$-hexane extract of the plant was found to possess the maximum $(6.65 \mathrm{mg} / \mathrm{gm}$ ) antioxidant capacity. The extracts revealed some total antioxidant capacity. On the other hand the methanol extract was found to contain highest (11.21 $\mathrm{mg} / \mathrm{gm})$ amount of flavonoids. From the results of the present study, it can be concluded that the plant extracts of $E$. variegate possess some antioxidant activities and this finding justifies its use as folk medicine.

\section{CONSENT}

It is not applicable.

\section{ETHICAL APPROVAL}

It is not applicable.

\section{COMPETING INTERESTS}

Authors have declared that no competing interests exist.

\section{REFERENCES}

1. Sofowora A. Medicinal plants and traditional medicine in Africa. John Wiley and Sons Ltd. 1982;7-9.

2. Ghani A. Medicinal plants of Bangladesh: Chemical constituents and uses. $1^{\text {st }}$ ed. Asiatic Society of Bangladesh: Mayor Books. 1998;11.

3. Kumar A, Lingadurai S, Jain A, Barman N. Erythrina variegata Linn: A review on morphology, phytochemistry and pharmacological aspects. Pharmacognosy Review. 2010;4(8):147-152. 
4. Shahriar M, Khair NZ, Akhter R, Chowdhury SF. In vitro thrombolytic activity of Erythrina variegate bark. World Journal of Pharmaceutical Research. 2015;4(5):512-515.

5. Yusuf M, Chowdhury JU, Wahab MA, Begum J. Medicinal plants of Bangladesh. Bangladesh Council of Scientific and Industrial Research, Dhaka, Bangladesh; 1994.

6. Harborne JB. Phytochemical methods: A guide to modern techniques of plant analysis. $3^{\text {rd }}$ ed. Chapman and Hall Int. Ed., New York; 1998;243-245.

7. Kokate CK. Pharmacognosy. $16^{\text {th }}$ ed. Niraliprakashani: Mumbai India. 2001; 117-119.

8. Meyer BN, Ferrigni NR, Putnam JE, Jacobsen JB, Nicholsand DE, Mclaughlin
JL. Brine shrimp: A convenient general bioassay for active plant constituents. Planta Medica. 1982;45(5):31-34.

9. Mclaughlin JL, Anderson JE, Rogers LL. The use of biological assays to evaluate botanicals. Drug Information Journal. 1998; 32:513-524.

10. Wang SY, Jiao $H$. Correlation of antioxidant capacities to oxygen radical scavenging enzyme activities in blackberry. Journal of Agricultural and Food Chemistry. 2000;48(11):5672-5676.

11. Prieto $\mathrm{P}$. Pineda $\mathrm{M}$. Aguilar $\mathrm{M}$. Spectrophotometric quantitation of antioxidant capacity through the formation of a phosphomolybdenum complex: Specific application to the determination of vitamin E. Analytical Biochemistry. 1999; 269(2):337-341.

(c) 2016 Shahriar et al.; This is an Open Access article distributed under the terms of the Creative Commons Attribution License (http://creativecommons.org/licenses/by/4.0), which permits unrestricted use, distribution, and reproduction in any medium, provided the original work is properly cited.

Peer-review history:

The peer review history for this paper can be accessed here: http://sciencedomain.org/review-history/12216 